JEL: F32, C22, C51

DOI: 10.5937/industrija42-5740

UDC:330.43:339.72.053(497.11)

"2002/2012"

Original Scientific Paper

\title{
Econometric Modelling of Serbian Current Account Determinants: Jackknife Model Averaging Approach ${ }^{2}$
}

\author{
Article history: \\ Received: 19 March 2014 \\ Sent for revision: 4 April 2014 \\ Received in revised form: 8 July 2014 \\ Accepted: 22 August 2014 \\ Available online: 1 November 2014
}

\begin{abstract}
This research aims to model Serbian current account determinants for the period Q1 2002 - Q4 2012. Taking into account the majority of relevant determinants, using the Jackknife Model Averaging approach, 48 different models have been estimated, where 1254 equations needed to be estimated and averaged for each of the models. The results of selected representative models indicate moderate persistence of the CA and positive influence of: fiscal balance, oil trade balance, terms of trade, relative income and real effective exchange rates, where we should emphasise: (i) a rather strong influence of relative income, (ii) the fact that the worsening of oil trade balance results in worsening of other components (probably non-oil trade balance) of $C A$ and (iii) that the positive influence of terms of trade reveals functionality of the Harberger-Laursen-Metzler effect in Serbia. On the other hand, negative influence is evident in case of: relative economic growth, gross fixed capital formation, net foreign assets and trade openness. What particularly stands out is the strong effect of relative economic growth that, most likely, reveals high citizens' future income growth expectations, which has negative impact on the CA.
\end{abstract}

Key words: Current account balance, current account determinants, Jackknife Model Averaging approach, unit root tests.

\footnotetext{
${ }^{1}$ Institute of Social Sciences, ppetrovic@idn.org.rs

2 The paper presents the results of a study conducted as a part of the project III47010, funded by the Ministry of Education, Science and Technological Development, Republic of Serbia, 2011-2014.
} 
Petrović P.: Econometric Modelling of Serbian Current Account Determinants...

\section{Ekonometrijsko modeliranje determinanti tekućeg bilansa Srbije: Jackknife Model Averaging pristup}

Apstrakt: Ovo istraživanje je posvećeno modeliranju determinanti tekućeg računa platnog bilansa Srbije za period Q1 2002 - Q4 2012. Uzimajući u obzir većinu relevantnih determinanti koje se javljaju u literaturi, primenom Jackknife Model Averaging tehnike, ocenjeno je 48 različitih modela, gde je za svaki model bilo potrebno oceniti 1254 jednačine i uprosečiti ih. Rezultati odabranih reprezentativnih modela pokazali su umerenu postojanost tekućeg računa platnog bilansa i pozitivan uticaj: fiskalnog salda, naftnog trgovinskog bilansa, odnosa razmene, relativnog dohotka i realnog efektivnog deviznog kursa, pri čemu treba naglasiti: (i) prilično snažan uticaj relativnog dohotka, (ii) činjenicu da pogoršanje naftnog trgovinskog bilansa utiče na pogoršanje ostalih komponenti tekućeg računa (najverovatnije preostalog dela spoljnotrgovinskog bilansa) i (iii) da pozitivan uticaj odnosa razmene otkriva funkcionalnost Harberger-Laursen-Metzler efekta u Srbiji. $S$ druge strane, negativan uticaj uočen je u slučaju: relativnog ekonomskog rasta, bruto fiksnih investicija, neto inostrane aktive i trgovinske otvorenosti. Naročito se ističe snažan efekat relativnog ekonomskog rasta koji najverovatnije otkriva velika očekivanja građana da će njihov dohodak u budućnosti rasti, što se negativno odražava na tekući račun.

Ključne reči: saldo tekućeg bilansa, determinante tekućeg računa, Jackknife Model Averaging pristup, testovi jediničnog korena.

\section{Introduction and Literature Review}

Determinants of current account balance have been attracting economists' attention recently and became a hot topic in the field of open economy macroeconomics. The levels and movements of current account balance incorporate important information about performances of national economies, in the same time providing precious recommendations to macroeconomic policy makers.

High current account deficits may be an introduction to a deep and severe recession, if caused by permanent internal imbalances, particularly if such an environment is supplemented by an exogeneous factor - the influence of global recession or recession in the immediate surroundings implying substantially developed economic relations. Current account imbalances may serve as an early warning system prior to a financial recession outbreak. This is particularly evident when the cause of deficit is high consumption (low saving), and substantially less when it is a matter of investment expansion, considering that investments contribute to economic growth and increased 
Petrović P.: Econometric Modelling of Serbian Current Account Determinants...

country's ability to pay off its external debt. The main risk emphasised by the researchers in relation to high current account deficits is a currency crisis that brings strong devaluation of domestic currency, implying numerous problems.

Ca' Zorzi, Chudik and Dieppe (2012) studied various current account models relying on three pretty convincing econometric strategies: (i) evaluation of all available models, (ii) selecting the best model using econometric and economic criteria and (iii) combining all models. Regardless of the approach, the authors have reached the conclusion that current account imbalances prevailed before the crisis in the United Kingdom, the United States, Japan and China. The second part of the analysis in the same tome covers the likelihood of models being "true" and estimation of uncertainty. Thousands (millions) of models lead to a unique conclusion - there is a minimum probability of current accounts being in accordance with the fundamentals prior to a crisis outbreak.

Jawaid and Raza (2012) studied determinants of current account deficit in Pakistan using the time series cointegration method. The results obtained indicate a long-run equilibrium relation between current account deficit, on one side, and exchange rate, trade deficit, fiscal deficit, external debt and private saving, on the other side. The obtained results show a positive influence of exchange rate, trade deficit and fiscal deficit and negative effect of external debt and private saving on current account deficit. Furthermore, a short term positive influence of exchange rate, trade deficit and fiscal deficit has been confirmed by the error correction model.

Ang and Sek (2012) tried to shed light on the determinants of current account balance for two different groups of countries: (i) for countries with current account deficit and (ii) for countries with current account surplus. Using the Generalised Method of Moments, the authors have reached the conclusion that there is a different impact of determinants on the current account surpluses and deficits. For example, reserve accumulation has impact on countries with deficits, while productivity only has impact on current account motion in economies with surpluses. Besides that, exchange rate, oil price and lagged current account have significant impact in majority of economies.

Urosevic, Nedeljkovic and Zildzovic (2012) analysed short to medium-term determinants of the current account balance for a selected group of CEE economies (the Czech Republic, Hungary, Poland, Romania and Serbia). Using the Jackknife Model Averaging techniques and including a set of explanatory variables (CA persistence, initial level of net foreign assets, oil trade balance, real effective exchange rate, trade integration, economic growth, relative income, foreign direct investment, terms of trade, financial development, fiscal balance and structural changes) the authors reached the conclusion that the estimated model is quite successful in describing the dynamics of current account balance during the past decade. Heterogeneity 
Petrović P.: Econometric Modelling of Serbian Current Account Determinants...

of signs and magnitudes of estimates for different countries justify the use of a country-level analysis.

Beidas-Strom and Cashin (2011) studied medium-term current account position, using dynamic panel regression, for three groups of developing countries (emerging markets; low-income and fragile economies; and net oil exporters) with common economic characteristics. The methodological framework used in the analysis is in fact an expansion of the list of IMF's Consultative Group on Exchange Rate (CGER) current account fundamentals by determinants relevant to Middle Eastern economies' current account. The study is related to evaluation of deviations of the actual medium-term current account position from the medium-term current account norms estimated using the model. The main conclusion is that expansion of the fundamental determinants results in convincing Middle Eastern current account norms that, in comparison with the actual and projected current account imbalances, for all three groups of countries, shows that current account imbalances are not excessive.

Clower and Ito (2011) conducted an econometric study of the statistical nature of the current account persistency with particular focus on its determinants. Assuming that the stationarity of current account series assures a long-run budget constraint and that countries may experience so called local nonstationarity in current account dynamics, the authors examined the current account law of motion for 70 selected countries. Using the Markov-switching ADF test that enables a switch in the dynamics of current account movements, the authors rejected the null hypothesis on non-stationarity for a substantial number of countries and formed significant differences between the countries in terms of periodical nature and duration of stationary and locally non-stationary regimes. The results show that the lack of trade openness, net foreign assets and financial development stimulate current account persistence, while exchange-rate regime is not a significant factor of current account persistence.

Greece is also one of the countries whose current account intrigued the researchers to attempt to discover its main macroeconomic, financial and structural determinants, first of all in terms of external sustainability (Brissimis, Hondroyiannis, Papazoglou, Tsaveas \& Vasardani, 2010). The problem of current account deficit in Greece particularly escalated in the period after 1999, showing an increasing dynamics and high persistence, which motivated the authors to analyse its causes, in the long-run and short-run, using the time series cointegration techniques. The research covered the period from 19602007 indicating that a statistically valuable model may be obtained if financial liberalisation is included as one of the regressors. In such a way estimated equilibrium model served as a basis for evaluation of current account position sustainability. 
Petrović P.: Econometric Modelling of Serbian Current Account Determinants...

Rahman (2008) studied current account movements in 10 new EU members: Czech Republic, Bulgaria, Estonia, Hungary, Latvia, Lithuania, Poland, Romania, Slovakia and Slovenia, having in mind the fact that on average have these countries had a substantially higher current account deficit than the average current account deficit of other developing countries during the past 15 years. Furthermore, during the past years, there are divergent flows between the countries as well. One group, comprising of the Baltic countries, Bulgaria and Romania, experienced a rapid growth of the current account deficit, while the other countries managed to achieve stability. In an attempt to answer the questions: (i) whether the high average current account deficit for the EU-10 countries is explained by medium-term macroeconomic fundamentals, (ii) what causes the divergence between the countries and (iii) how challenging is it for the countries that have experienced rapid deficit growth to attempt to invert the trend, the author used panel data for 59 countries, expanding the vector of standard determinants of current account movements with two additional variables - FDI and private remittances.

Chinn and Ito (2007) also attempted to investigate: (i) whether the behaviour of the U.S. current account is an exception to experience of the other industrial countries, (ii) whether it is possible to reliably anticipate the dynamics of East Asian current account balances using standard macroeconomic variables expanded with additional institutional variables and (iii) could a high level of financial development in the key East Asian economies result in lower current account surpluses. The results obtained indicate that an increase in the budget balance for 1 percentage point would increase the current account balance for approximately $0.10-0.49$ percentage points, implying that the U.S. current account movement during the past four years is bordering with deviance. Financial development of the key East Asian countries has resulted in higher saving. The dynamics of the current account balance in East Asian countries is more shaped by decreased investments than by increased saving.

Engel and Rogers (2006) developed a simple long term model according to which current account is determined by the expected discounted present value of its future share of world GDP, relative to its current share of world GDP. The theoretical model showed that, in case of a reasonable assumption of a more modest future economic growth in the U.S. in comparison to other developed countries, the level of the current account deficit is close to optimal. Besides, testing the current account sustainability points to the fact that the U.S. are not on a path sustainable in the long run. The use of the model has shown that the pattern of behaviour of the U.S. current account can hardly be explained on the basis of expectations of future U.S. growth. Still, if the data on estimated economic growth of G-7 countries are considered, the theoretical model gives a very good explanation of the genesis of the U.S. current account. 
Petrović P.: Econometric Modelling of Serbian Current Account Determinants...

Nason and Rogers (2006) have, using the post-war Canadian data, confirmed the common rejection of the present-value model of the current account. Investigating the reasons for it, the authors were calibrating and simulating different versions of the real business cycle model, which resulted in real business cycle model close to the data, but quite far from the present-value model estimation. Having in mind that expanding the model by adding the world real interest rate shock has significantly improved its ability to fit the data, the authors conclude that there is an important common world component of the current account dynamics, indicating that there are additional macroeconomic variables influencing the current account volatility pattern.

In his paper, Aristovnik (2006) investigated key determinants of current account deficits in order to evaluate its potential of being excessive in the selected Eastern Europe countries and the former Soviet Union. The author finds that, in the 2000-2003 period, actual current account balances were quite close to their estimated values calculated on the basis of selected determinants. In other words, such findings are in accordance with the intertemporal approach to the current account, because the current account deficits are a logical consequence of the fact that the current income is lower than the permanent income, i.e. that the current investments are above their permanent levels.

An empirical research of the medium-term determinants of current account balances for a group of industrial and developing countries, using crosssection and panel regression econometric techniques, revealed that the current account positively correlated with public finance balances and initial stocks of net foreign assets (Chinn \& Prasad, 2003). On the other hand, when it comes to developing countries, current account balance is positively correlated with measures of financial deepening, but negatively associated with indicators of openness to international trade.

The paper consists of six parts. The first part gives a review of certain problems that may arise from a high current account deficit as well as results of some of the most influential studies in the field. The second part provides an explanation of the methodology used for the analysis, while the third part explains the method of quantifying the individual variables. The fourth and fifth part, respectively, show the research results and the most important findings. Finally, the reference list is provided in the sixth part. 
Petrović P.: Econometric Modelling of Serbian Current Account Determinants...

\section{Methodology}

\subsection{Current Account Model and Determinants Explanation}

This study is mainly focused on testing medium-term current account balance determinants for Serbia because of their empirical characterisation. All potential determinants have been selected on the basis of a detailed review of rich empirical literature, with emphasis on Ca' Zorzi et al., (2012); Aristovnik, (2006); Chinn \& Prasad, (2003), which resulted in compiling the following general current account model:

$$
C A_{t}=f\left[\begin{array}{l}
C A_{t-1}, N F A_{t}, O B_{t}, I_{t}, R G D P G_{t}, F B_{t}, R I_{t}, T O_{t},\left(F I_{t}, F D E E_{t}, F D_{t}\right), \\
R E E R_{t}, T O T_{t}
\end{array}\right],
$$

where the determinants, in the order as they are listed, represent: lagged current account $\left(C A_{t-1}\right)$, initial level of net foreign assets $\left(N F A_{t}\right)$, oil trade balance $\left(O B_{t}\right)$, investment $\left(I_{t}\right)$, real GDP growth $\left(R G D P G_{t}\right)$, fiscal balance $\left(F B_{t}\right)$, relative income $\left(R I_{t}\right)$, trade openness $\left(T O_{t}\right)$, financial integration $\left(F I_{t}\right)$ [financial deepening $\left(F D E E_{t}\right)$; financial development $\left(F D_{t}\right)$ ], real effective exchange rate $\left(R E E R_{t}\right)$ and terms of trade $\left(T O T_{t}\right)$.

$C A$ persistence $\left(C A_{t-1}\right)$. Many studies show that there is a strong persistence in the CA movements, which is highly connected to habit formation in consumption and savings of countries. Besides, agglomeration in investment and income inflows also lead to an increase of current account persistence. Therefore, the regression coefficient is expected to be positive.

Initial net foreign assets $\left(N F A_{t}\right)$. The countries that show a high value of NFA have high positive income flows, which improve the current account balance. On the other hand, countries with high NFA are in a position to record high foreign trade deficits while, in the same time, preserving external liquidity and solvency. Therefore, it is unclear what the influence NFA will have on current account, so we conclude that the sign of estimation is ambiguous.

Oil balance $\left(O B_{t}\right)$. Oil trade balance has positive influence on the current account balance. This variable is used in order to model a country's susceptibility to changes in oil prices. If there is dependence on oil import, any price increase will impair the current account balance.

Investment $\left(I_{t}\right)$. Investments increase future productivity and expected national wealth providing the opportunity for an increase in current consumption (intertemporal adjustment) and current account deficit. Furthermore, increased investments imply current account deficit to the extent to which investments exceed gross saving. Undoubtedly, an increase in investments may result in increased aggregate demand and higher foreign trade deficit, 
Petrović P.: Econometric Modelling of Serbian Current Account Determinants...

and, thereby, higher current account deficit. Therefore, negative sign is expected.

Real GDP growth (RGDPG $)$. Real GDP growth increases employees' and household's expectations that their future income will grow, resulting in increased current consumption and current account deficit. Furthermore, GDP growth rarely affects growth of export and by increased aggregate demand it is always, at least partially, correlated with import growth and external deficit. In other words, negative sign is expected.

Fiscal balance $\left(F B_{t}\right)$. Fiscal balance, according to many models, has positive impact on the current account balance in the medium term. For instance, overlapping generations models point to the fact that fiscal deficit implies flow of future income into the present and, thereby, current account deficit. Furthermore, the twin deficit hypothesis implies positive correlation between fiscal balance and the current account. Therefore, positive sign is expected.

Relative income $\left(R I_{t}\right)$. Countries with low income in comparison to other developed countries have a strong need for external financing and, therefore, their current account deficit is also higher. Besides that, low relative income in such countries leads to higher expected future income, due to the catching-up process. On the other hand, when countries reach a relatively high income level, it is expected that their relative income will be diminishing in the future, which stimulates increased current savings and the current account improvement. Positive sign is expected in this case.

Trade openness $\left(T O_{t}\right)$. Trade openness may have dual impact on the current account balance. On the one hand, the countries that impose higher trade barriers may decrease import and improve their current accounts. On the other hand, higher trade barriers generally mean retaliation by foreign trade partners, closing the doors to the country's export and deterioration of trade and the current account balance. The sign of the coefficient is ambiguous.

Financial integration $\left(F I_{t}\right)$ [financial deepening $\left(F D E E_{t}\right)$; financial development $\left.\left(F D_{t}\right)\right]$. The determinant shows the level of sophistication and internationalisation of a financial system. The logic behind the influence is the following: (i) the more sophisticated a financial system, the higher the saving, due to more options for each achievement and higher returns that may be earned, (ii) more sophisticated and diverse financial system means less limitations for borrowing, higher consumption, i.e. lower savings. Therefore, the sign of this coefficient is ambiguous.

Real effective exchange rate $\left(R E E R_{t}\right)$. Although it may impact in various ways, the sign of the real effective exchange rate is most commonly associated with the elasticity approach. Specifically, real effective exchange rate appreciation (i.e. its decrease) decreases export price competitiveness. The effect depends on the value of elasticity of import and export volume to a 
Petrović P.: Econometric Modelling of Serbian Current Account Determinants...

change in relative prices caused by exchange rate changes. In other words, exchange rate appreciation impairs foreign trade and current account balances which is why we expect a positive relationship between real effective exchange rate and current account.

Terms of trade $\left(T_{O} T_{t}\right)$. Terms of trade may have dual impact on the current account balance. The first channel of influence is the fact that a positive change in terms of trade leads to a higher current relative to permanent income and, thereby, to an improvement of the current account balance (the Harberger-Laursen-Metzler effect). The second channel of influence means that an improvement in terms of trade may result in the increase of the optimal capital stock and an increase in investments, thereby impairing the current account balance. Which channel will dominate depends on the persistence of terms of trade shocks. The higher the persistence, the stronger the second channel and vice versa.

\subsection{Econometric Methodology}

The econometric technique used in the research is known as the "jackknife model averaging" (JMA) approach, which was developed by Hansen and Racine (2012), and, the same year, extended to time series by Liu (2012). One of the main questions in the statistics and econometrics literature is how to deal with model uncertainty in a situation when there are many potential regressors and models. Generally speaking, there are two basic approaches for solving this problem. The first one is based on the choice of an appropriate selection criterion, such as the Akaike information criterion (AIC) or Schwarz information criterion (SIC), and then, out of a set of potential models, selecting the one that satisfies the criterion the best. Although the approach may be the most popular one, its drawback lies in the fact that there are many selection criteria suggested in the literature and each criterion favours different model. The fact can be relatively easily exploited with an intention to select a model that suits the researcher the most.

The other approach is based on averaging over the set of candidate models by using an established algorithm. The majority of averaging methods rely on sample splitting and homoscedasticity, which substantially limits their application. The findings of Hansen and Racine (2012) are the only known results of model averaging allowing for heteroscedasticity. The authors have shown that the JMA estimators are asymptotically optimal because they have the lowest possible expected squared error over the class of linear estimators in the presence of heteroscedastic errors.

The summary version of the JMA approach is presented according to Hansen and Racine (2012, pp. 39-40). Assume a set of independent observations $\left(y_{i}\right.$, 
Petrović P.: Econometric Modelling of Serbian Current Account Determinants...

$\left.x_{i} ; i=1,2, \ldots, n\right)$, so that the conditional mean can be expressed as $\mu_{i}=\mu\left(x_{i}\right)=E\left(y_{i} \mid\right.$ $\left.x_{i}\right)$. In this case, a set of variables $y_{i}$ may be expressed as:

$y_{i}=\mu_{i}+e_{i}$,

where a zero conditional expected value and heteroscedasticity of error term are assumed:

$$
\begin{aligned}
& E\left(e_{i} \mid x_{i}\right)=0, \\
& \sigma_{i}^{2}=E\left(e_{i}^{2} \mid x_{i}\right) .
\end{aligned}
$$

In order to provide clearer short equations, we are introducing the following vector labels: $y=\left(y_{1}, y_{2}, \ldots, y_{n}\right)^{\prime} ; \mu=\left(\mu_{1}, \mu_{2}, \ldots, \mu_{n}\right)^{\prime} ; e=\left(e_{1}, e_{2}, \ldots, e_{n}\right)^{\prime}$. Assume that, for $\mu$, there is a total of $M_{n}$ possible linear estimators $\left\{\hat{\mu}^{1}, \hat{\mu}^{2}, \ldots, \hat{\mu}^{M n}\right\}$, where linearity implies the possibility to represent any estimator as a linear combination of $y$, i.e. $\hat{\mu}^{m}=P_{m} y$, where $P_{m}$ is not a function of $y$. This technique does not impose any limitations on the value $M_{n}$, giving it a big advantage, bearing in mind that the number of estimators in a practical research may be quite large. In the case of least-squares estimators, $P_{m}$ is expressed as $P_{m}=X^{m}\left(X^{m^{\prime}} X^{m}\right)^{-1} X^{m^{\prime}}$, where $X^{m}$ represents a matrix of regressors and the $i$ 'th row of $X^{m}$ is $x_{i}^{m}$. Model averaging approach requires averaging across estimators:

$$
\hat{\mu}(w)=\sum_{m=1}^{M_{n}} \omega^{m} \hat{\mu}^{m}=\hat{\mu} w=P(w) y,
$$

where

$$
\begin{aligned}
& w=\left(\omega^{1}, \omega^{2}, \ldots, \omega^{M n}\right)^{\prime}, \\
& \hat{\mu}=\left(\hat{\mu}^{1}, \hat{\mu}^{2}, \ldots, \hat{\mu}^{M n}\right), \\
& P(w)=\sum_{m=1}^{M_{n}} \omega^{m} P_{m},
\end{aligned}
$$

a set of non-negative weights which sum to one, $n \times M_{n}$ matrix of estimates and linear operator indexed by $w$, respectively. The key question here is which criterion to use to select the $w$ weight vector. 
Hansen and Racine (2012) suggested the jackknife selection of $w$ known as the leave-one-out cross-validation. The procedure requires an estimation of jackknife residuals for the averaging estimator. The $m$ 'th jackknife estimator $\tilde{\mu}^{m}=\left(\tilde{\mu}_{1}^{m}, \tilde{\mu}_{2}^{m}, \ldots, \tilde{\mu}_{n}^{m}\right)^{\prime}$ is computed so that for each $\tilde{\mu}_{i}^{m}$ i'th observation is deleted, and may be represented as $\tilde{\mu}^{m}=\tilde{P}_{m} y$, with zeros on the diagonal of $\widetilde{P}_{m}$. The residual vector for the $m^{\prime}$ th jackknife estimator is $\tilde{e}^{m}=y-\tilde{\mu}^{m}$.

The jackknife averaging estimator can be calculated in the following way:

$\tilde{\mu}(w)=\sum_{m=1}^{M_{n}} \omega^{m} \tilde{\mu}^{m}=\tilde{\mu} w=\tilde{P}(w) y$,

where $\tilde{\mu}=\left(\tilde{\mu}^{1}, \tilde{\mu}^{2}, \ldots, \tilde{\mu}^{M n}\right)$.

If $\tilde{e}=\left(\tilde{e}^{1}, \tilde{e}^{2}, \ldots, \tilde{e}^{M n}\right)$ is $n \times M_{n}$ matrix of residuals, the jackknife averaging residual vector is:

$\tilde{e}(w)=y-\tilde{\mu}(w)=\sum_{m=1}^{M n} \omega^{m} \tilde{e}^{m}=\tilde{e} w$

The jackknife procedure selects the weight vector $\hat{w}$ in such a way to minimise the estimate of expected true error (the least squares crossvalidation criterion):

$$
C V_{n}(w)=\frac{1}{n} \tilde{e}(w)^{\prime} \tilde{e}(w),
$$

and the JMA estimator is $\hat{\mu}(\hat{w})=\hat{\mu} \hat{w}$.

In simple terms, the use of the JMA approach in the CA determinants modelling context requires all candidate models (total $M_{n}$ ) obtained by creating all combinations without repetition for potential regressors, to be estimated first. That case is known in the literature as non-nested case. Nested case, however, means that the first model is formulated in relation to two regressors (for example $x_{1}$ and $x_{2}$ ), and then the following models by gradually expanding the previous one $\left(x_{1}, x_{2}\right.$ and $\left.x_{3}\right)$, etc. After evaluating all $M_{n}$ potential models, jackknife residuals have to be calculated, in order to create the least squares cross-validation criterion, minimisation of which determines the weight vector. Applying weights, calculated in the described way, on previously estimated CA models, results in the JMA estimator. 
Petrović P.: Econometric Modelling of Serbian Current Account Determinants...

\section{Data}

Quarterly data used in the research cover the period between Q1 2002 and Q4 2012.

Table 1. Variables used in the empirical research

\begin{tabular}{|c|c|c|c|c|}
\hline Variable & Label & $\begin{array}{c}\text { Deviation from } \\
\text { trading } \\
\text { partners }\end{array}$ & $\begin{array}{l}\text { Expected } \\
\text { influence }\end{array}$ & Description \\
\hline $\begin{array}{l}\text { Current account } \\
\text { balance }\end{array}$ & $C A_{t-1}$ & No & + & $\begin{array}{l}\text { Current account as a } \\
\text { share of GDP }\end{array}$ \\
\hline $\begin{array}{l}\text { Initial net foreign } \\
\text { assets }\end{array}$ & $N F A_{t}$ & No & ambiguous & $\begin{array}{l}\text { Net foreign assets } \\
\text { as a share of } \\
\text { GDP at the end of } \\
\text { the previous period }\end{array}$ \\
\hline Oil balance & $O B_{t}$ & No & + & $\begin{array}{c}\text { Oil trade balance as } \\
\text { a share of GDP }\end{array}$ \\
\hline $\begin{array}{l}\text { Logarithm of } \\
\text { investment }\end{array}$ & $L N I_{t}$ & Yes & - & $\begin{array}{c}\text { Gross fixed } \\
\text { investments as a } \\
\text { share of GDP }\end{array}$ \\
\hline $\begin{array}{l}\text { Logarithm of real } \\
\text { GDP growth }\end{array}$ & $L_{N R G D P G S A}$ & Yes & - & $\begin{array}{l}\text { Real GDP growth } \\
\text { seasonally adjusted }\end{array}$ \\
\hline Fiscal balance & $F B_{t}$ & Yes & + & $\begin{array}{l}\text { Fiscal balance as a } \\
\text { share of GDP }\end{array}$ \\
\hline $\begin{array}{l}\text { Logarithm of } \\
\text { relative income }\end{array}$ & LNRISA $_{t}$ & Yes & + & $\begin{array}{l}\text { Real GDP per capita } \\
\text { seasonally adjusted }\end{array}$ \\
\hline $\begin{array}{l}\text { Logarithm of trade } \\
\text { openness }\end{array}$ & $\mathrm{LNTO}_{t}$ & No & ambiguous & $\begin{array}{l}\text { Ratio of exports plus } \\
\text { imports of goods } \\
\text { and } \\
\text { nonfactor services to } \\
\text { GDP }\end{array}$ \\
\hline $\begin{array}{c}\text { Logarithm of } \\
\text { financial integration }\end{array}$ & $L N F I_{t}$ & No & ambiguous & $\begin{array}{c}\text { Sum of external } \\
\text { assets and liabilities } \\
\text { as a share of GDP }\end{array}$ \\
\hline $\begin{array}{c}\text { Logarithm of } \\
\text { financial deepening }\end{array}$ & $L_{N F D E E_{t}}$ & No & ambiguous & Ratio of M3 to GDP \\
\hline $\begin{array}{l}\text { Logarithm of } \\
\text { financial } \\
\text { development }\end{array}$ & $L N F D_{t}$ & No & ambiguous & $\begin{array}{l}\text { Credit to companies } \\
\text { as a share of GDP }\end{array}$ \\
\hline $\begin{array}{l}\text { Logarithm of real } \\
\text { effective exchange } \\
\text { rate }\end{array}$ & $L N R E E R_{t}$ & No & + & $\begin{array}{l}\text { Trade-weighted real } \\
\text { eff. exch. rate }\end{array}$ \\
\hline $\begin{array}{l}\text { Logarithm of terms } \\
\text { of trade }\end{array}$ & $\mathrm{LNTOT}_{t}$ & No & ambiguous & $\begin{array}{l}\text { Index, price of } \\
\text { exports/price of } \\
\text { imports, goods }\end{array}$ \\
\hline
\end{tabular}

Source: Author 
Petrović P.: Econometric Modelling of Serbian Current Account Determinants...

All variables may be classified in two groups, as follows: (i) variables constructed for Serbia only $\left(C A_{t}, N F A_{t}, O B_{t}, T O_{t}, T O T_{t}, F I_{t}, F D E E_{t}, F D_{t}\right.$, $R E E R_{t}$ ); and (ii) variables calculated as deviation from weighted averages for 14 most important export destinations $\left(I_{t}, R G D P G_{t}, F B_{t}, R I_{t}\right.$ ), where the weights are shares of individual countries in the total export of goods from Serbia during 2006-2012, comprising about $80 \%$ of the total export. The indices necessary to calculate some variables (TOT $T_{t} R G D P G_{t}$ and $R E E R_{t}$ ) have been constructed using Q1 2002 as the base period. Real effective exchange rate index was formulated in such a way that values above one indicate depreciation. The data necessary to create the aforementioned series were taken from the official websites: of national statistical offices, central banks, ministries of finance, EUROSTAT, World Economic Outlook Database (WEO) and World DataBank - World Development Indicators (WDI).

The following table shows a list of variables, basic information on how they are calculated, as well as expected influence on the current account balance. Detailed information about the methods used in constructing the variables is available upon request.

\section{Results of the Empirical Research}

The first step in analysing the CA determinants is to test the order of integration of the individual series, considering that the JMA technique can only be applied to $\mathrm{I}(0)$ processes. Testing non-stationarity of time series was conducted using: (i) standard unit root tests without structural breaks (augmented Dickey-Fuller - ADF, Ellioth-Rothenberg-Stock - DF-GLS, Phillips-Perron - PP and Kwiatkowski-Phillips-Schmidt-Shin - KPSS) and (ii) endogenous one and two-break LM Lee and Strazicich (LS) unit root tests, having in mind that the dynamics of most series raises doubt over the presence of structural breaks. The number of lags in the ADF test necessary to eliminate autocorrelation was determined following the "specific to general" approach and number of additional lags in the DF-GLS test follow the ADF specification. Finally, when using the PP and KPSS tests, the Newey-West correction with Bartlett kernel was applied. 
Petrović P.: Econometric Modelling of Serbian Current Account Determinants...

Table 2. Unit Root Tests Results

\begin{tabular}{|c|c|c|c|c|c|c|c|}
\hline \multirow{2}{*}{ Variable/test } & \multirow{2}{*}{ dc $k$} & \multirow{2}{*}{ ADF } & \multirow{2}{*}{ DF-GLS } & \multirow{2}{*}{ PP } & \multirow{2}{*}{ KPSS } & \multicolumn{2}{|c|}{ LS } \\
\hline & & & & & & $\mathrm{m} \mathrm{b} \mathrm{k}$ & ts \\
\hline CA & C 0 & $\begin{array}{l}-2.93 \\
(-2.92)\end{array}$ & $\begin{array}{l}-2.70 \\
(-1.95)\end{array}$ & $\begin{array}{l}-2.82 \\
(-2.92)\end{array}$ & $\begin{array}{c}0.23 \\
(0.46)\end{array}$ & A $20 \begin{array}{l}(2009: 01) \\
(2012: 01)\end{array}$ & $\begin{array}{c}-3.86 \\
(-3.84)\end{array}$ \\
\hline NFA & C 9 & $\begin{array}{l}-2.15 \\
(-2.95)\end{array}$ & $\begin{array}{c}0.03 \\
(-1.95)\end{array}$ & $\begin{array}{c}-7.78 \\
(-2.93)\end{array}$ & $\begin{array}{c}0.49 \\
(0.46)\end{array}$ & C $25 \begin{array}{l}(2005: 03) \\
(2007: 03)\end{array}$ & $\begin{array}{l}-7.62 \\
(-5.29)\end{array}$ \\
\hline OB & c 0 & $\begin{array}{l}-3.41 \\
(-2.93)\end{array}$ & $\begin{array}{l}-3.32 \\
(-1.95)\end{array}$ & $\begin{array}{l}-3.43 \\
(-2.93)\end{array}$ & $\begin{array}{c}0.12 \\
(0.46)\end{array}$ & A $20 \begin{array}{l}(2006: 02) \\
(2008: 03)\end{array}$ & $\begin{array}{c}-5.28 \\
(-3.84)\end{array}$ \\
\hline LNI & C 4 & $\begin{array}{l}-2.33 \\
(-2.94)\end{array}$ & $\begin{array}{c}0.48 \\
(-1.95)\end{array}$ & $\begin{array}{c}-6.14 \\
(-2.93)\end{array}$ & $\begin{array}{c}0.66 \\
(0.46)\end{array}$ & C $27 \begin{array}{l}(2004: 03) \\
(2011: 04)\end{array}$ & $\begin{array}{c}-7.71 \\
(-5.29)\end{array}$ \\
\hline LNRGDPGSA & c 3 & $\begin{array}{l}-1.88 \\
(-2.94)\end{array}$ & $\begin{array}{c}-0.12 \\
(-1.95)\end{array}$ & $\begin{array}{l}-4.59 \\
(-2.93)\end{array}$ & $\begin{array}{c}0.56 \\
(0.46)\end{array}$ & C $27 \begin{array}{l}(2004: 03) \\
(2009: 01)\end{array}$ & $\begin{array}{l}-5.98 \\
(-5.29)\end{array}$ \\
\hline FB & C 4 & $\begin{array}{l}-1.30 \\
(-2.94)\end{array}$ & $\begin{array}{c}-0.69 \\
(-1.95)\end{array}$ & $\begin{array}{c}-5.76 \\
(-2.93)\end{array}$ & $\begin{array}{c}0.41 \\
(0.46)\end{array}$ & A $20 \begin{array}{l}(2004: 04) \\
(2008: 04)\end{array}$ & $\begin{array}{c}-6.52 \\
(-3.84)\end{array}$ \\
\hline LNRISA & $c+t 3$ & $\begin{array}{c}-0.28 \\
(-3.53)\end{array}$ & $\begin{array}{c}-0.25 \\
(-3.19)\end{array}$ & $\begin{array}{l}-2.92 \\
(-3.52)\end{array}$ & $\begin{array}{c}0.21 \\
(0.15)\end{array}$ & C $23 \begin{array}{l}(2004: 04) \\
(2009: 04)\end{array}$ & $\begin{array}{l}-5.31 \\
(-5.29)\end{array}$ \\
\hline LNTO & $c+t$ & $\begin{array}{l}-3.66 \\
(-3.52)\end{array}$ & $\begin{array}{c}-3.31 \\
(-3.19)\end{array}$ & $\begin{array}{l}-3.56 \\
(-3.52)\end{array}$ & $\begin{array}{c}0.14 \\
(0.15)\end{array}$ & A $10(2008: 03)$ & $\begin{array}{c}-4.32 \\
(-3.57)\end{array}$ \\
\hline LNFI & $\mathrm{c}+\mathrm{t}$ & $\begin{array}{l}-2.83 \\
(-3.51)\end{array}$ & $\begin{array}{l}-1.86 \\
(-3.19)\end{array}$ & $\begin{array}{l}-6.84 \\
(-3.51)\end{array}$ & $\begin{array}{c}0.14 \\
(0.15)\end{array}$ & A $20 \begin{array}{l}(2005: 04) \\
(2012: 01)\end{array}$ & $\begin{array}{l}-3.75 \\
(-3.84)\end{array}$ \\
\hline LNFDEE & $\mathrm{c}+\mathrm{t} \varepsilon$ & $\begin{array}{l}-0.02 \\
(-3.53)\end{array}$ & $\begin{array}{l}-1.11 \\
(-3.19)\end{array}$ & $\begin{array}{l}-3.74 \\
(-3.51)\end{array}$ & $\begin{array}{c}0.19 \\
(0.15)\end{array}$ & C 16 (2007:01) & $\begin{array}{c}-3.03 \\
(-4.45 \text { to }-4.51)\end{array}$ \\
\hline LNFD & $c+t 9$ & $\begin{array}{c}-1.95 \\
(-3.53)\end{array}$ & $\begin{array}{c}-1.31 \\
(-3.19)\end{array}$ & $\begin{array}{l}-6.93 \\
(-3.51)\end{array}$ & $\begin{array}{c}0.13 \\
(0.15)\end{array}$ & A $25 \begin{array}{l}(2007: 04) \\
(2012: 01)\end{array}$ & $\begin{array}{l}-2.76 \\
(-3.84)\end{array}$ \\
\hline LNREER & $c+t 1$ & $\begin{array}{l}-3.18 \\
(-3.51)\end{array}$ & $\begin{array}{l}-2.29 \\
(-3.19)\end{array}$ & $\begin{array}{l}-3.59 \\
(-3.51)\end{array}$ & $\begin{array}{c}0.12 \\
(0.15)\end{array}$ & C $21 \begin{array}{l}(2003: 03) \\
(2007: 04)\end{array}$ & $\begin{array}{c}-3.84 \\
(-5.29)\end{array}$ \\
\hline LNTOT & $\mathrm{c}+\mathrm{t} 0$ & $\begin{array}{l}-5.57 \\
(-3.52)\end{array}$ & $\begin{array}{c}-5.45 \\
(-3.19)\end{array}$ & $\begin{array}{l}-5.56 \\
(-3.52)\end{array}$ & $\begin{array}{c}0.07 \\
(0.15)\end{array}$ & C $20 \begin{array}{l}(2004: 01) \\
(2010: 01)\end{array}$ & $\begin{array}{c}-7.28 \\
(-5.29)\end{array}$ \\
\hline
\end{tabular}

Note: dc represents deterministic components in ADF, DF-GLS, PP and KPSS tests, $\mathbf{k}$ the number of lags which aim to eliminate autocorrelation in residuals in ADF and LS tests, $\mathbf{m}$ model type in LS test, b number of breaks, tb timing of the break and ts LS test statistics. Critical values at $5 \%$ significance level are shown in the parentheses. LS critical values are taken from Lee and Strazicich (2003, p. 1084; 2004, p. 12). The testing was conducted using software packages EViews 5.1 and RATS 8.0.

Source: Author

Testing the order of integration of the individual series (Table 2), using standard unit root tests, gives unambiguous results only in case of oil balance $\left(O B_{t}\right)$, trade openness $\left(L N T O_{t}\right)$, terms of trade $\left(L N T O T_{t}\right)$ and relative income $\left(L N R I S A_{t}\right)$. By applying all tests, we reach the conclusion that the first three series are I(0) processes and the last one is an I(1) process, at a significance level of $5 \%$. In all other cases, there are differences in results obtained using different unit root tests. Nevertheless, having in mind that movement of time series suggests presence of structural breaks, the testing was conducted using the LS test. The results show that the real effective exchange rate $\left(L N R E E R_{t}\right)$, financial integration $\left(L N F I_{t}\right)$, financial deepening $\left(L N F D E E_{t}\right)$ and financial development $\left(L N F D_{t}\right)$ are $\mathrm{I}(1)$ processes, while all the other series 
Petrović P.: Econometric Modelling of Serbian Current Account Determinants...

are stationary. When using the JMA technique, we have considered the firstdifferences of the aforementioned non-stationary series.

Table 3. JMA Estimation Results

\begin{tabular}{lccc}
\hline \hline & Model 1 & $\begin{array}{c}\text { Coefficient estimates } \\
\text { Model 2 }\end{array}$ & Model 3 \\
\hline C & 135.915 & 144.007 & 138.958 \\
CA-1 & 0.259 & 0.236 & 0.219 \\
$\Delta($ LNFD, LNFDEE, LNFI) & - & - & - \\
FB & 0.067 & 0.012 & 0.113 \\
LNRGDPGSA & -1.074 & -1.001 & -1.080 \\
LNI-1 & $x$ & -0.015 & $x$ \\
LNI-2 & -0.053 & $x$ & -0.050 \\
NFA & -0.179 & -0.185 & -0.185 \\
OB & 1.875 & 1.401 & 2.041 \\
$\Delta$ LNREER & 0.192 & $x$ & $x$ \\
$\Delta$ LNREER-2 & $x$ & 0.220 & 0.139 \\
LNRISA & 0.718 & 0.803 & 0.736 \\
LNToT & 0.082 & 0.077 & 0.074 \\
LNTO & -0.023 & -0.109 & -0.033 \\
\hline & 0.612 & 0.609 & 0.631 \\
\hline
\end{tabular}

Note:,$- x$ and $\Delta$ represents zero values, omitted variables and first-differences of time series, respectively. The estimations for logarithmically transformed variables represent semi-elasticity coefficients. The estimating was conducted using software package Matlab R2013a.

Source: Author

During the research, various model specifications were estimated, depending on whether the model encompasses: (i) financial integration $\left(F I_{t}\right)$, financial deepening $\left(F D E E_{t}\right)$ or financial development $\left(F D_{t}\right)$; (ii) real effective exchange rates without time lags and with first-order, second-order and third-order time lag; (iii) gross fixed capital formation without time lags and with first-order, second-order and third-order time lag, giving a total of 48 different models. Every model was estimated using the JMA technique by forming all combinations with four, five and six regressors (a total of 1254 equations), where only the constant appears as a core variable (it is present in every equation). After estimating the aforementioned models, we have singled out the models that make economic sense, in terms of the sign and magnitude of obtained estimations (Table 3). Furthermore, it appears that the models are very well positioned in terms of size of $R^{2}$. In this regard, we prefer the third model as it provides the best explanation of the CA movements.

The results obtained indicate a moderate persistence of the CA balance, i.e. that one percentage point increase in the lagged CA leads to a 0.219-0.259 percentage points increase of the $C A$, indicating a relatively rapid stabilisation of CA following temporary shocks. 
Petrović P.: Econometric Modelling of Serbian Current Account Determinants...

Regardless of how we quantify the degree of sophistication and internalisation of the financial system (financial integration, financial deepening or financial development), three equal models in which the first-difference of the variable has no statistical significant influence on the CA always stands out. Having in mind that the first-difference of the time series was included in the model, due to non-stationarity, it is impossible to draw conclusions about effects of the original variable.

One percentage point increase in general government fiscal balance results in 0.012-0.113 percentage points increase in the CA, where we prefer the second value as it refers to a somewhat more representative model. The effect is most likely in the range between 0.067 and 0.113 and it is closer to the upper value of the coefficient. As expected, the sign of estimation is positive.

A change in relative economic growth has a rather strong influence on the $C A$ balance, with expected negative sign. In fact, one percent increase in the variable leads to 1.001-1.080 percentage points decrease in the CA balance, therefore confirming that the mechanism of citizens' expectations that their future income will grow on the basis of their current economic prosperity is most certainly present in Serbia, which is reflected in increased current consumption and the current account deficit.

One percent increase in gross fixed capital formation results in worsening of the CA balance by 0.015 percentage points (if the investments have the firstorder time lag), i.e. by $0.050-0.053$ percentage points (if the investments have the second-order time lag). As more representative, we consider higher values, due to the fact that we are dealing with models that explain a larger percentage of CA variability.

Regarding the influence of net foreign assets, the results reveal that the effect of perception that growth of NFA gives the possibility for higher spending and import, while in the same time preserving external liquidity and solvency, is widespread in Serbia. Therefore, the influence is negative and indicates that one percentage point increase in NFA implies worsening of the CA balance by $0.179-0.185$ percentage points.

As expected, the sign for oil balance is positive but what is interesting is that it is greater than one. In fact, the estimated parameters indicate that one percentage point increase in oil trade balance results in 1.401-2.041 percentage points increase of the CA balance. At first glance, the result is somewhat surprising because, having in mind that $O B$ is a part of $C A$, it is expected that, ceteris paribus, one percentage point increase in $O B$ would increase the CA balance by one percentage point. The results, however, show that the CA increase is higher than one, indicating that ceteris paribus does not apply, i.e. that there is interaction between different components of 
Petrović P.: Econometric Modelling of Serbian Current Account Determinants...

the CA. A possible mechanism of influence could be that worsening of $O B$ induced by oil price increase is reflected on inflation in Serbia more intensively than in other countries, perhaps due to relatively low retail competition. Higher inflation in Serbia than abroad generates positive inflation differential which, if not alleviated by changes in the nominal exchange rate, leads to the loss of price competitiveness of domestic products, increased imports and worsening of the foreign trade balance excluding oil balance. In other words, worsening of the $\mathrm{OB}$, caused by oil price surge, may be reflected on increased import of other products and further worsening of the CA balance. This mechanism is purely intuitive and we have no evidence of its effectiveness. Precise explanation of reasons behind the more intense CA balance worsening requires a detailed and deeper analysis and that is not the aim of this research.

Figure 1 Actual and Fitted Current Account Movements
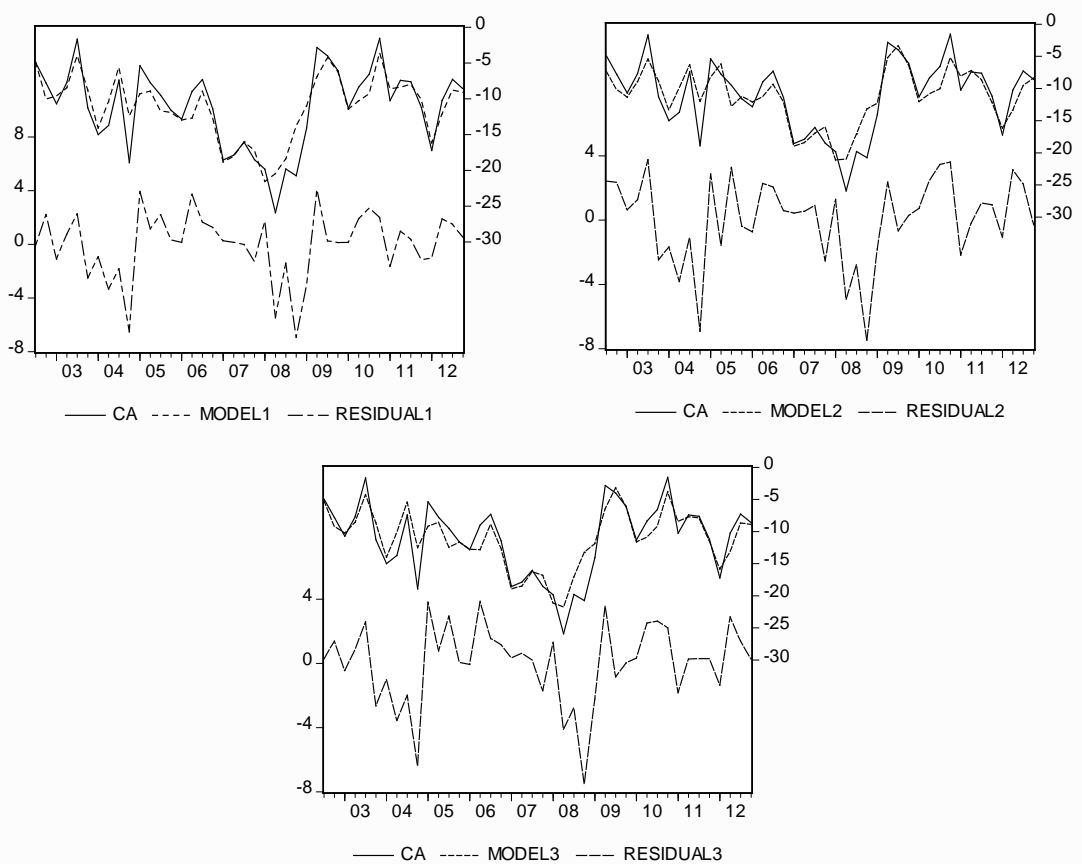

Source: Author

The real effective exchange rate is, due to non-stationarity, included in the modelling as the first-difference. The estimations obtained indicate that one- 
Petrović P.: Econometric Modelling of Serbian Current Account Determinants...

percent acceleration of chain growth leads to improved CA balance by 0.139 -0.220 percentage points.

Relative income has a positive and quite a strong effect on the CA balance. One percent change in relative income results in CA balance change by 0.718 -0.803 percentage points.

The terms of trade estimations indicate that the Harberger-Laursen-Metzler effect is characteristic for Serbia, i.e. that a positive change in terms of trade leads to a higher current relative to permanent income and CA improvement. One-percent improvement in terms of trade results in improved CA balance by $0.074-0.082$ percentage points.

Quite expectedly for Serbia, trade openness estimation has negative sign. The country's opening up, following the political changes in 2001, debt writeoffs, relatively generous donations and remittances, foreign loans, privatisation revenues, along with foreign trade liberalisation, have resulted in quite a dynamic import growth and worsening of the CA balance. Opening up of an uncompetitive economy, which is not enough export oriented, like Serbia, with plentiful foreign capital inflows for various reasons, prepares a fertile ground for the CA deterioration. One percent increase in openness results in CA worsening by $0.023-0.109$ percentage points, though, considering the estimation characteristic for the third model, the actual effect is probably closer to the lower limit.

\section{Conclusion}

This research aims to model Serbian CA balance determinants during the period between Q1 2002 and Q4 2012. The econometric model was made by including most of the variables mentioned in literature that can be properly quantified. For some of the determinants, like age dependency ratio (old/youth dependency ratio), only annual data are available and mathematical disaggregation of annual series produces methodical problems, such as possible I(2) non-stationarity, which is why the variable has been, justifiably, left out from the model.

In order to obtain an appropriate and economically meaningful model, we experimented with various specifications. Namely, during quantification of the degree of sophistication and internationalisation of the financial system, three alternative variables were used (financial integration, financial deepening or financial development), where all three of them were combined with the real effective exchange rate and gross fixed capital formation without time lags and with first-order, second-order and third-order time lag. That way, 48 different model specifications were estimated. Considering that the number of 
Petrović P.: Econometric Modelling of Serbian Current Account Determinants...

potential CA determinants is substantial, we have selected the JMA (not model selection) technique to deal with the parametric model uncertainty and limited number of observations. Therefore, each of the aforementioned 48 specifications has been estimated by forming all possible combinations with four, five and six regressors (a total of 1254 equations), with the constant as the core variable, and then, the results obtained were averaged by appropriate weights. By rejecting the models that make no economic sense (due to unexpected estimation sign or statistical insignificance of important regressors) we have selected three representative models and based the conclusions on them.

The estimation results show moderate persistence of the CA and positive influence of: fiscal balance, oil trade balance, terms of trade, relative income and real effective exchange rates. A rather strong influence of relative income and oil balance should be emphasised. Worsening of the oil balance, through unknown channels, results in worsening of other components (probably nonoil trade balance) of CA. Furthermore, positive influence of terms of trade reveals functionality of the Harberger-Laursen-Metzler effect in Serbia.

On the other hand, there was a negative influence in the case of: relative economic growth, gross fixed capital formation, net foreign assets and trade openness. What specifically stands out is an intense influence of relative economic growth which, most likely, reveals strong citizens' expectations that, based on current economic growth, their future income will grow, which results in reduced savings and worsening of the CA. Apart from that, a relatively rapid economic growth probably leads to increased aggregate demand which is partially directed to increased import and trade deficit. A similar effect is produced by an increase in the gross fixed capital formation, but also according to the saving-investment approach, the variable generates CA deficit when it increases above the level of gross savings. The negative influence of net foreign assets shows that the idea that an increase in NFA facilitates increased import and foreign trade deficit without endangering external liquidity is predominant in Serbia. Finally, trade openness, fully expectedly, has negative sign, showing that foreign trade liberalisation, with debt write-off, relatively plentiful donations and remittances, foreign loans and privatisation revenues, has resulted in increased import and worsened CA balance.

\section{References}

Ang, H.Y., \& Sek, S.K. (2012). A comparative study on the determinants of current account surpluses and deficits.International Journal of Humanities and Applied Sciences (IJHAS), 1(1), 1-5. Retrieved from http://psrcentre.org/proceeding.php?type $=4$ 
Petrović P.: Econometric Modelling of Serbian Current Account Determinants...

Aristovnik, A. (2006). The determinants and excessiveness of current account deficits in Eastern Europe and former Soviet Union. William Davidson Institute Working Paper, 827, $\quad$ Retrieved from http://deepblue.lib.umich.edu/bitstream/handle/2027.42/57207/wp827\%20.pdf?seq uence $=1$

Beidas-Strom, S., \& Cashin, P. (2011). Are middle eastern current account imbalances excessive. IMF Working Paper,Retrieved from http://www.imf.org/external/pubs/ft/wp/2011/wp11195.pdf

Brissimis, S.N., Hondroyiannis, G., Papazoglou, C., Tsaveas, N.T., \& Vasardani, M.A. (2010). Current account determinants and external sustainability in periods of structural change. ECB Working Paper, 1243, Retrieved from http://www.ecb.europa.eu/pub/pdf/scpwps/ecbwp1243.pdf

Ca'zorzi, M., Chudik, A., \& Dieppe, A. (2012). Thousands of models, one story: Current account imbalances in the global economy. Journal of International Money and Finance, 31(6), 1319-1338. doi:10.1016/j.jimonfin.2012.02.003

Menzie, C.D., \& Hiro, I. (2007). Current account balances, financial development and institutions: Assaying the world 'saving glut'. Journal of International Money and Finance, 26(4), 546-569. doi:10.1016/j.jimonfin.2007.03.006

Chinn, M.D., \& Prasad, E.S. (2003). Medium-term determinants of current accounts in industrial and developing countries: An empirical exploration. Journal of International Economics, 59(1), 47-76. Retrieved from http://www.sciencedirect.com.proxy.kobson.nb.rs:2048/science/journal/00221996/5 9/1 doi:10.1016/S0022-1996(02)00089-2

Clower, E., \& Ito, H. (2011). The persistence and determinants of current account balances: The implications for global rebalancing. Retrieved from http://sciie.ucsc.edu/workingpaper/2011/CA persistency Clower Ito.pdf

Engel, C., \& Rogers, J.H. (2006). The U.S. current account deficit and the expected share of world output. Journal of Monetary Economics, 53(5), 1063-1093. doi:10.1016/j.jmoneco.2006.05.002

Hansen, B.E., \& Racine, J.S. (2012). Jackknife model averaging. Journal of Econometrics, 167(1), 38-46. doi:10.1016/j.jeconom.2011.06.019

Jawaid, S.T., \& Raza, S.A. (2012). Dynamics of current account defcit: A lesson from Pakistan. Transition Studies Review,19(3), 357-366. doi:10.1007/s11300-0120251-5

Liu, (. (2012). A plug-in averaging estimator for regressions with heteroskedastic errors. Retrieved

from http://faculty.chicagobooth.edu/midwest.econometrics/Papers/MEGCLiu.pdf

Nason, J.M., \& Rogers, J.H. (2006). The present-value model of the current account has been rejected: Round up the usual suspects. Journal of International Economics, 68(1), 159-187. doi:10.1016/j.jinteco.2005.01.004

Rahman, J. (2008). Current account developments in new member states of the European Union: Equilibrium, excess, and EU-phoria. IMF Working Paper, Retrieved from https://www.imf.org/external/pubs/ft/wp/2008/wp0892.pdf

Urošević, B., Nedeljković, M., \& Zildžović, E. (2012). Jackknife model averaging of the current account determinants.Panoeconomicus, 59(3), 267-281. doi:10.2298/PAN1203267U 